\title{
Personnel-marketing as a direction of development of personnel agricultural complex
}

\author{
Dmitry Yadransky ${ }^{1}$, Rinat Latypov ${ }^{1, *}$ and Elena Chumak $^{1}$ \\ ${ }^{1}$ Ural State University of Economics, Institute of economics, 6201448 March street/Narodnaya \\ Volya, 62/45, Yekaterinburg, Russia
}

\begin{abstract}
The article considers the ambivalence of personnel marketing as a modern management technology that allows balancing on the principles of the mutual agreement the interests of employers and employees in a situation of choice in the segment of the labor market. The problem of the article lies in the need to search for tools to effectively build (develop) the labor market of agricultural enterprises. Personnel marketing technologies are proposed as tools. Research methods are: methods of theoretical generalization, logical modeling, induction, and other general scientific methods. The article defines the main directions and mechanisms for the development of personnel marketing as a modern social management technology that ensures the tactical and strategic development of company personnel. The possibility of promoting the attractiveness of jobs at agricultural enterprises through the use of external and internal tools of personnel marketing is being considered.
\end{abstract}

\section{Introduction}

Personnel marketing issues are quite relevant in modern Russian literature and affect the interests of a large number of people. There is a common understanding of the importance of marketing staff in providing the effective management tasks of a modern organization. Analyzing the works of authors whose full-text works are presented on the Elibrary.ru resource, we note that there are two different approaches to the issue of personnel marketing. The representative of the first is A. Mikhailova and co-authors, who in their works $[13 ; 14 ; 1]$ consider personnel marketing (HR-marketing) as "a type of managerial activity based on the application of the marketing methodology in the human resources management system and aimed at creating and developing intellectual capital with maximum consideration for the needs of the enterprise in personnel and the situation on the labor market"'[14].

A. Makhmetova adheres to the same logic [11, p. 112], she considers personnel marketing as a direction for analyzing the situation on the labor market to effectively cover staffing requirements for realizing the organization's goals. A similar logic is presented in the textbook edited by A. Kibanov [6, p. 249], as well as A. Pikhach, who considers marketing staff as a means of avoiding a crisis caused by a lack of staff [15].

\footnotetext{
* Corresponding author: latypov.rinat@mail.ru
} 
The second direction in the understanding of personnel marketing is represented by the work of M. Menshikova and co-authors who believe that "the fundamental task of personnel marketing is to create the maximum possible attractive image of an enterprise as an employer to provide itself with human resources with optimal quantitative and qualitative parameters [10]. Some authors consider marketing personnel a means of evaluating and modeling careers [5]. Others - a means of building staff profiles [19].

Some authors consider the marketing approach basis to the organization's personnel policy [2]. Common in these approaches is the recognition of the fact of the most efficient use of personnel. It should be noted that staff can be considered not only as an internal resource of the organization. It can be used outside the organization - being subcontracted, outsourced, etc. Both of these approaches, in our opinion, are quite relevant for agricultural enterprises.

Without going into a deep terminological analysis, we consider it necessary to clarify the methodological approaches to personnel marketing in the conditions of agricultural enterprises. Analyzing modern scientific concepts of the interpretation of marketing, four of them can be distinguished [10, c. 7]:

- marketing as a management concept;

- marketing as a system for achieving certain goals;

- marketing as a method;

- marketing as a philosophy, as a market-oriented thinking style.

Marketing approaches, taking into account the occurrence of a shortage of jobs, are simultaneously applied by both employers (to search for an employee) and the employees themselves (to search for jobs). These technologies are less common in agricultural enterprises. The paradox of agricultural enterprises is that often the employer and employee are, in a sense, monopolists in the local labor market. Such monopolism often does not lead to the emergence of unconditional employment, but rather, to the emergence of other forms of competition (refusal of employment, departure, dumping of the offer price), which accordingly negatively affects the prospects of this segment of the labor market.

\section{Method}

The above allows us to formulate the problem of the article, which consists of the fact that there is a need to search for tools to develop an effective labor market for agricultural enterprises. We see staff marketing technologies as such a tool.

Research methods are: methods of theoretical, logical modeling, induction, other general scientific methods.

In our opinion, the conditions for effective marketing activities in the field of personnel management are already formed in the labor market of agricultural enterprises:

- the market for buyers of labor services is relatively stable, as a result of which an internal labor market has emerged in most enterprises;

- competition both between employees and between employers (for employees with high or specific skills);

- the employee and the employer form a long-term motivation in the field of employment;

- the employee has the opportunity to refuse employment using exit migration;

- the conditions for the free movement of capital have been formed [20], which further increases mobility in the labor market.

At the same time, the data of the Federal State Statistics Service [17] for the period 2005-2013 indicate that the proportion of other costs (except for labor compensation) in other (non-agricultural) sectors is much higher. The results are shown in table 1. 
Table 1. The Dynamics of the structure of personnel costs

\begin{tabular}{|c|c|c|c|c|c|c|c|}
\hline & \multicolumn{7}{|c|}{ Including } \\
\hline & $\begin{array}{l}\text { Labor } \\
\text { costs } 1\end{array}$ & wage & \begin{tabular}{|c|} 
expenses for \\
providing \\
workers with \\
housing \\
\end{tabular} & $\begin{array}{l}\text { social } \\
\text { protection } \\
\text { costs }\end{array}$ & $\begin{array}{l}\text { training } \\
\text { costs }\end{array}$ & \begin{tabular}{|} 
expenses \\
for \\
cultural \\
services \\
\end{tabular} & other costs \\
\hline \multicolumn{8}{|c|}{ Total for surveyed activities } \\
\hline 2005 & 100 & 76,6 & 0,4 & 19,6 & 0,3 & 0,7 & 2,4 \\
\hline 2007 & 100 & 77,9 & 0,3 & 18,5 & 0,3 & 0,5 & 2,5 \\
\hline 2009 & 100 & 78,1 & 0,3 & 18,4 & 0,3 & 0,4 & 2,5 \\
\hline 2013 & 100 & 75,4 & 0,2 & 21,5 & 0,3 & 0,3 & 2,4 \\
\hline \multicolumn{8}{|c|}{ Manufacturing } \\
\hline 2005 & 100 & 75,5 & 0,3 & 20,4 & 0,3 & 1,2 & 2,3 \\
\hline 2007 & 100 & 76,8 & 0,2 & 19,7 & 0,3 & 0,8 & 2,2 \\
\hline 2009 & 100 & 76,9 & 0,1 & 20,0 & 0,3 & 0,6 & 2,1 \\
\hline 2013 & 100 & 74,2 & 0,2 & 22,5 & 0,3 & 0,5 & 2,3 \\
\hline \multicolumn{8}{|c|}{ of which: food production, including drinks and tobacco } \\
\hline 2005 & 100 & 78,4 & 0,2 & 19,1 & 0,2 & 0,4 & 1,7 \\
\hline 2007 & 100 & 79,5 & 0,1 & 18,6 & 0,2 & 0,3 & $1,1,3$ \\
\hline 2009 & 100 & 79,8 & 0,0 & 18,6 & 0,1 & 0,2 & 1,2 \\
\hline 2013 & 100 & 76,7 & 0,0 & 21,8 & 0,1 & 0,2 & 1,1 \\
\hline
\end{tabular}

Source: compiled by the authors

The demonstrated dynamics indicate that the expenses of agricultural enterprises are oriented towards monetary payments to employees. The costs of cultural, domestic, professional, and other development are below average. So according to data for the period from 2013 to 2019 , the share of the rural population decreased from $26 \%$ to $25.41 \%$ [18]. All of the above gives reason to argue that the workers of agricultural enterprises in modern conditions have the opportunity to act relatively autonomously based on their benefits. It should be noted the significant influence of stakeholders on the activities of these organizations. Modern conditions of the labor market for the professions in the agricultural sector indicate the emergence of mutual competition, which determines the freedom of choice of market participants. Consequently, raising questions about the strategic prospects for the development of agricultural enterprises against the background of a general outflow of the rural population becomes problematic.

Due to the lack of a clear structure of marketing activities in the field of personnel management of agricultural enterprises, the process of interaction between the labor market (both internal and external) and the carriers of labor resources (workers) is still chaotic without a clearly defined concept of interaction. As studies by domestic and foreign authors show, modern processes in various labor markets are characterized by a violation of the psychological contract with the employee expressed in the absence of: 1) justice in distribution, 2) procedural justice and 3) justice in interactions [3]. In our opinion, these results are entirely relevant for agricultural enterprises.

As a result of the lack of a concept, not all active and high-quality labor resources can find full (adequate) use in places of residence. The share of unused (used unproductively, off-profile) labor resources creates negative factors for the development of agricultural enterprises and negatively affects the life of the resource owners themselves, as a result of which the labor resource is lost. It is possible to maximally effectively satisfy the entire set 
of needs of the carriers of labor resources of agricultural enterprises using personnel marketing tools.

\section{Study detail and result}

Marketing-oriented social technologies require a targeted impact on the social space to organize and maintain effective and balanced cases of exchange (both single and in the system). The classic scenario of marketing activities implies an impact on the behavior of the buyer in the process of making a purchasing decision [9].

The peculiarity of staff marketing is that each of the participants in the marketing process acts both as an object and as a subject of marketing activity (in an enterprise, in the labor market, in economic life). In the system of classical marketing, an object acts as an enterprise that is interested in marketing its products, and as a subject, potential consumers of products [16, p. 9].

This chain for marketing staff acquires a binary character - in the process of "buying" an employee, the company "sells" a specific workplace that a particular worker "buys". As a result, for both participants in this interaction, the result of marketing actions is the determination of the price of the employment contract. The presence in parallel of two differently directed but based on common social mechanisms processes determines the specific requirements for personnel marketing. Adapting the thesis expressed by B. Golodets about the signs of technology of marketing activity [10], to the issues of personnel marketing we can state:

- time constraints - the availability of clear information about the start and end of the activity, about the period of maximum effectiveness of the planned activities, which allows you to design the actions of the staff;

- optional repeatability of all marketing tools (the repeatability of individual tools is required);

- particularity or uniqueness, which implies differences in instrumental approaches to various areas of marketing;

- variability - since technology always assumes the existence of alternative methods of activity [10, p. 249]. The direct specificity of marketing approaches has differences. First of all, the differences in technologies implemented by the parties in the framework of the initial "sale" of the workplace and implemented to maintain its attractiveness. The technologies implemented by the employee in competition in the external and internal labor markets will also change.

In the book of V.V. Tomilov and L.N. Semerkova "Labor Marketing" [20] it is proposed to use the following methodological approaches to this type of marketing activity:

- firstly, market activity should be oriented towards consumers of the labor force employers, customer orientation means studying not the employers' production capabilities but the needs of the market, and, based on this, developing a plan for their satisfaction;

- secondly, orientation to other subjects of market relations should be taken into account. In particular, the ability of employees to adapt to the conditions of changing demand for labor, as well as their requirements for wages, production conditions, work and rest, etc .;

- thirdly, a focus on a systematic approach should be implemented. All types of activities related to the sale of labor services in marketing conditions should be coordinated and operate synchronously;

- fourthly, the basic principle of marketing should be a long-term orientation [20,7].

In our opinion, these principles do not sufficiently take into account the dual nature of marketing interaction in the labor process. Moreover, they come from the resource concept of staff. Modern qualified personnel is no longer a classic workforce, possessing a set of 
unique (sometimes irreplaceable) knowledge. In this case, it is advisable to use the project approach since a specific set of competencies is determined by specific (project) goals.

Agribusinesses do not always use the opportunity to increase capacity building for fear of a possible outflow of personnel. Studies by colleagues revealed the institutional barriers that were most significant in the demand for competence: strict internal planning, disclosure of information, strategic behavior of the company, excessive preferences for the same professions, etc. [8]. For agricultural enterprises, we would supplement the list with complex forecasting of market conditions in the agricultural market. The use of low-skilled personnel also poses significant risks for agricultural enterprises. The logic of marketing staff can be applied to eliminate this contradiction. The main thesis is the assertion that the internal labor market for an employee should be constantly more attractive than the external market. Moreover, this logic is associated with the satisfaction of the needs of the employee, not only in material terms. We focus on the pyramid of needs of A. Maslow in the description of needs. A set of some tools to meet possible needs is given in table 2 .

Table 2. Tactical tools of personnel marketing in the agricultural enterprise

\begin{tabular}{|l|l|l|}
\hline \multicolumn{1}{|c|}{ Needs } & \multicolumn{1}{|c|}{ Internal tools } & \multicolumn{1}{|c|}{ External tools } \\
\hline Physiological & $\begin{array}{l}\text { Stable salary, social package (food, } \\
\text { recreation), work schedule }\end{array}$ & $\begin{array}{l}\text { Personnel outsourcing to increase } \\
\text { load during low season) }\end{array}$ \\
\hline Safety & $\begin{array}{l}\text { Guaranteed working conditions, } \\
\text { organization of a workplace, tools, } \\
\text { andon }\end{array}$ & $\begin{array}{l}\text { Assistance in providing infrastructure } \\
\text { (including social), social package }\end{array}$ \\
\hline $\begin{array}{l}\text { Love and } \\
\text { belonging }\end{array}$ & $\begin{array}{l}\text { Labor content, corporate events, } \\
\text { professional mobility, training, } \\
\text { kaizen, andon }\end{array}$ & $\begin{array}{l}\text { HR-image of the company, } \\
\text { cooperation with other companies, } \\
\text { training }\end{array}$ \\
\hline Esteem & $\begin{array}{l}\text { Professional skills contests, corporate } \\
\text { professional development programs, } \\
\text { KPI, conditions for professional } \\
\text { implementation }\end{array}$ & $\begin{array}{l}\text { External professional skills contests, } \\
\text { public awareness, conditions for prof. } \\
\text { implementation (outsourcing) }\end{array}$ \\
\hline $\begin{array}{l}\text { Self- } \\
\text { actualization }\end{array}$ & $\begin{array}{l}\text { Ability development, corporate } \\
\text { training, promotion, rotation }\end{array}$ & $\begin{array}{l}\text { Education, advanced training, } \\
\text { development of social infrastructure }\end{array}$ \\
\hline
\end{tabular}

Source: compiled by the authors

In table 2, we assume that external tools are also the result of the organization's activities aimed at meeting the needs of employees. The satisfaction of these needs occurs outside the organization, focusing both on the satisfaction of needs and on their formation (including those who are not included in labor relations). Thus, it seems possible to implement a systematic approach proposed by V. Tomilov and L. Semerkova [20].

\section{Discussion}

The main functional specificity of personnel marketing as a social technology is the presence of counter-marketing flows of both informational and material nature on the part of each of the participants in social interaction.

Creating a holistic system of personnel marketing requires the construction of instrumental social mechanisms of managerial impact. In the process of implementing the concept of personnel marketing at the agricultural enterprises, special attention is paid to modern technologies of network interaction. It allows giving the existing communication processes the character of informal ties. Such relationships exist in many agricultural enterprises, but often mainly at the lower level of social interaction.

A set of social influence methods aimed at meeting the needs indicated in Table 2 may contain a range of methods of social regulation, social regulation, moral incentives, etc. Our 
proposed logic of personnel management based on marketing technologies requires the development of specific tools based on the characteristics of a particular branch of an agricultural company based on the needs of the people who make up the core of this team.

\section{References}

1. D.G. Dayants, A.B. Mikhailova, Mining information and analytical bulletin, 12, 293298 (2009) (In Russ.)

2. M.A. Dymshakov, Journal of Economy and entrepreneurship, 12-1(77-1), 598-601 (2016) (In Russ.)

3. A.E. Fedorova, Z. Dvorzhakova, I. Katsane, H. Khan, M.S. Menshikova, The Manager, 10(1), 52-61 (2019) (In Russ.)

4. Fromm Erich. Psychoanalysis and Religion; The Art of Loving; To have or to be? (Translation from English, Nika Center, 1998)

5. Jarosławska-Sobór Sylwia, MINIB, 17(3), 37-53 (2015)

6. A.Ya Kibanov, Personnel management of the organization. 3rd ed. supplemented and revised (INFRA-M., 2005) (In Russ.)

7. Lyudmila Pavlovna Kiyan, Labor Market Marketing (Publishing House of Voronezh State University, 1995) (In Russ.)

8. A.Yu. Kokovikhin, T.A. Kansafarova, The Manager, 9(3), 76-81 (2018) (In Russ.)

9. Kotler Philip, The basics of marketing (JSC «Koruna»: AOZT «Litera plus», 1994) (In Russ.)

10. N.V. Lopatina, Sociology of marketing (OJSC "Printing House - Vyatka", 2005) (In Russ.)

11. A.E. Makhmetova, Vestnik of Saratov State Socio-Economic University, 3, 111-15 (2009) (In Russ.)

12. M.A. Menshikova, L.A. Afanasyeva, E.N. Zaikin, Vestnik of Kursk State Agricultural Academy, 7, 10-13 (2014) (In Russ.)

13. A.B. Mikhailova, Mining information and analytical bulletin, 6(12), 240-253 (2009) (In Russ.)

14. A.B. Mikhailova, D.G. Dayants, Mining information and analytical, 420, 300-07, (2014) (In Russ.)

15. A.Yu. Prikhach, Actual issues of economic science, 21-2 (2011) https://cyberleninka.ru/article/n/znachenie-marketinga-personala-dlya-realizatsiikadrovoy-politiki

16. T.A. Priyemka, Marketing (MAUP, 2004) (In Russ.)

17. The cost structure of organizations for labor by type of economic activity. Official resource of the Federal State Statistics Service of the Russian Federation https://www.gks.ru/storage/mediabank/3-1-2.htm (In Russ.)

18. The share of urban population in the total population as of January 1. The official resource of the Federal State Statistics Service of the Russian FederationT https://showdata.gks.ru/report/278932/ (2019) (In Russ.)

19. A.A. Tijnema, J.A. Melnichuk, A.A. Ivanova, New generation, 16, 112-116 (2018) (In Russ.)

20. V.V. Tomilov, S. Semerkova, Labor force marketing (Publishing House of St. Petersburg State University of Economics and Finance,1997) (In Russ.) 
21. I.V. Shcherbakov, Economics: yesterday, today, tomorrow, 7(3-a), 5-13 (2017) (In Russ.) 